\title{
Erratum to: A Region Under Threat? Climate Change Impacts, Institutional Change and Response of Local Communities in Coastal Yucatán
}

\author{
Lysann Schneider and Tobias Haller
}

\section{Erratum to:}

Chapter 10 in: W. Leal Filho and J.M. Keenan (eds.), Climate Change Adaptation in North America, Climate Change Management, https://doi.org/10.1007/978-3-31953742-9_10

The original version of the book was inadvertently published with incorrect author name "M.A. Lysann Schneider" which has been corrected to read as "Lysann Schneider" in Chapter 10. 